\title{
Burgercooperaties. Speler of speelbal in de nieuwe verhoudingen tussen overheid, markt en samenleving
}

Meike Bokhorst, Jurian Edelenbos, Joop Koppenjan, Mirjan Oude Vrielink.

Bokhorst, M, Edelenbos, J., Koppenjan, J.F.M. \& Oude Vrielink, M. (2015). Burgercooperaties. Speler of speelbal in de nieuwe verhoudingen tussen overheid, markt en samenleving. Bestuurskunde, 24 (2), 3-16.

Inleiding bij het themanummer: Bokhorst, M, Edelenbos, J., Koppenjan, J.F.M. \& Oude Vrielink, M. (2015). Themanummer A New Kid in Town. Burgercoöperaties. Bestuurskunde, 24 (2), 1-62.

\section{Leader}

Burgers hebben in Nederland het afgelopen decennium in allerlei sectoren initiatieven ontwikkeld en coöperaties opgericht om zelf voorzieningen en diensten tot stand te brengen en te beheren. Kennelijk slagen overheid en markt er onvoldoende in om in bepaalde behoeften en daarmee samenhangende waarden van burgers leven te voorzien. Hoewel burgercoöperaties jonge organisaties zijn die zichzelf grotendeels nog moeten bewijzen, zijn de koplopers een bron van inspiratie, innovatie en navolging. Tegelijk kunnen we constateren dat er weinig kennis beschikbaar is over deze nieuwe organisatievorm. Het ontbreekt tot nu toe aan empirische sectorstudies en een systematische vergelijking. Dit themanummer inventariseert en vergelijkt the state of art van burgercoöperaties op het terrein van energie, zorg, breedband en wonen. Hoe effectief en duurzaam zijn burgercoöperaties en hoe verhouden ze zich tot overheden, marktpartijen en maatschappelijke organisaties? De vergelijkende analyse laat zien dat burgercoöperaties moeten leren om te gaan met de spanning tussen het streven naar zelfbeheer en de behoefte tot professionalisering. Ook moeten ze leren samen te werken met andere partijen in hun omgeving. Coöperaties moeten leren het spel mee te spelen zodat zij geen speelbal van andere partijen worden.

\section{Coöperaties als de 'echte helden' van de terugtredende overheid?}

"Texel heeft toch ooit al een energiemaatschappij gehad, waarom doen we dat niet weer?" Die opmerking tijdens een lezing over duurzame energie was voor een groep Texelse burgers aanleiding om in $\mathbf{2 0 0 7}$ het idee voor een energiecoöperatie uit te werken. Inmiddels is Texel Energie uitgegroeid tot een veel geprezen energiecoöperatie die in het hele land navolging kreeg. De oprichters van Zorgcoöperatie Hoogeloon en stadsdorp Amsterdam-Zuid zagen in het buitenland inspirerende voorbeelden van eigen regie over ouderenzorg en werden vervolgens zelf een inspirerend voorbeeld voor burgers, bestuurders en politici. Burgercoöperaties zijn 'virale organisaties'; zij steken elkaar aanprikkelen reguliere organisaties om anders naar hun voorzieningen en diensten te kijken. Dat roept de vraag op wat er eigenlijk zo aanstekelijk is, maar ook wat er beklijft van burgercoöperaties als praktijk van zelforganisatie.

Op tal van terreinen richten burgers momenteel coöperaties op, het meest prominent op het gebied van energie, zorg, wonen, wijk- en dorpsgemeenschappen en breedband. Kenmerk van deze burgercoöperaties is dat ze van onderop ontstaan, vanuit zelforganisatie. In de 
(natuurwetenschappelijke) literatuur wordt onder zelforganisatie het spontane ontstaan van nieuwe structuren uit complexe processen van lokale interactie verstaan (Jantsch, 1980; Heylighen, 2001). Denk bijvoorbeeld aan een zwerm spreeuwen. Zonder sturing van buitenaf passen spreeuwen hun gedrag tijdens de vlucht onderling aan en ontstaan spontane vormen van gecoördineerd gedrag. In de vertaling naar sociale wetenschappen, in het bijzonder bestuurskunde, is er bij zelforganisatie sprake van een duurzaam maatschappelijk initiatief van burgers, dat (grotendeels) los van bestaande instituties is ontstaan, waarbij verantwoordelijkheid en organiserend vermogen voor een belangrijk deel in handen blijft van de initiatiefnemers (Van der Velden, 2010; Van Ginneken, 2013).

In het bestuurskundige perspectief vormen initiatieven van zelforganisatie niet uitsluitend een ontwikkeling 'van onderop'. In een landschap van overheidsorganisaties, regels en procedures dat in de loop van de tijd is opgebouwd, wordt zelforganisatie in overheidsbeleid ook 'van bovenaf' gepropageerd. In 2010 is bijvoorbeeld in de troonrede de participatiesamenleving 'afgekondigd'. Hieruit blijkt dat de overheid de ontwikkeling van zelforganisatie serieus neemt, omdat het past bij het beleid van de terugtredende overheid en het benadrukken van eigen burgerverantwoordelijkheid voor diensten en voorzieningen in verschillende sectoren (bijv. zorg, educatie, sport en cultuur). Zo kiezen gemeenten faciliterende rollen om zelforganisatie bijvoorbeeld in de vorm van burgercoöperaties te ondersteunen (Edelenbos, Van Meerkerk en Batenburg, 2009).

Voor de ontwikkeling waarin burgers meer verantwoordelijkheid in het (semi-)publieke domein nemen én krijgen, zijn in de wetenschappelijke en beleidsliteratuur diverse begrippen in omloop: actief burgerschap (Tonkens, 2009), bewonersinitiatieven (Oude Vrielink en Van de Wijdeven, 2008), burgerinitiatieven (Heijden e.a., 2007; Edelenbos e.a., 2009; Oude Vrielink en Verhoeven, 2011), de doe-democratie (Van de Wijdeven en Hendriks, 2010; BZK, 2013), de doe-het-zelf democratie (Van Twist e.a., 2009), burgerkracht (De Boer en Van der Lans, 2011), maatschappelijk initiatief (Houwelingen e.a., 2014) en samenredzaamheid (Hendriks e.a., 2014). Dat burgers in het (semi)publieke domein zelf het heft in handen nemen, vormt de gemene deler in de omschrijvingen. Als mensen elkaar daarbij rond een idee, initiatief, ideaal of belang vinden en zich op één lijn weten op te stellen, is er sprake van zelforganisatie (Huygen e.a., 2012, p. 10; Nienhuis, 2014).

Zelforganisatie vraagt - het woord zegt het al - organisatie, anders is het initiatief geen lang leven beschoren (Brouwer en Engbersen, 2013, p. 62). Burgers kunnen zich op verschillende manieren rond een maatschappelijk initiatief organiseren. In dit themanummer stellen we coöperatie als vorm centraal. In de internationale literatuur bestaan hiervan verschillende definities, die een aantal gezamenlijke kenmerken delen.' Een coöperatie is:

- een onderneming, een organisatie gericht op het realiseren of beheer van een voorziening of dienst;

- een autonome organisatie, een sociale eenheid die zelfstandig kan functioneren;

- in eigendom van leden, waarbij de leden zeggenschap hebben over de koers van de organisatie;

- een organisatievorm, waarbij het belangrijkste doel niet het genereren van winst is, maar het voorzien in de (economische, sociale of culturele) behoeften van de leden.

Bij een burgercoöperatie organiseren burgers zich door een zakelijke relatie met elkaar aan te gaan, waarbij leden zeggenschap hebben over de koers van de onderneming en delen in de winst. De 
organisatie neemt dan de vorm aan van een coöperatie in culturele zin. De rechtsvorm bepaalt of er ook sprake is van een coöperatie in juridische zin. In Nederland houdt dit de keuze voor de coöperatieve vereniging in.

Volgens De Moor (2013) is er momenteel sprake van een 'derde golf' van coöperatieve zelforganisatie. In de eerste golf (1000-1800) ontstonden instituties voor collectieve acties zoals begijnhoven, gilden, markegenootschappen en waterschappen. In de 'tweede golf' (1880-1950) ontstaan nieuwe instituties voor collectieve actie, gericht op het collectief organiseren van coöperaties (waaronder onderlinge waarborgfondsen), vakverenigingen en vele nieuwe (erkende) verenigingen met culturele of sportieve doelstellingen. Na een periode van verstatelijking is nu sprake van een derde golf (ongeveer vanaf 2005) waarin burgers zich verenigen - vaak in coöperaties - om publieke diensten en voorzieningen te ontwikkelen en te beheren. De Verenigde Naties hebben 2012 zelfs uitgeroepen tot jaar van de coöperatie.

In het recente themanummer van dit blad over de terugtredende overheid noemde Frissen (2014, p. 68) deelnemers aan burgercoöperaties de 'echte helden' van de terugtocht. Dit is wrang omdat dit lijkt te suggereren dat burgercoöperaties de terugtocht van de overheid en de daarmee gepaard gaande bezuinigingen en afbouw van overheidsvoorzieningen faciliteren. Maar deze coöperaties zijn vaak juist een reactie daarop. En in veel gevallen willen ze zelfs helemaal niets met overheid of markt te maken hebben. Kenmerkend voor coöperaties is juist dat zij autonoom willen opereren (Huygen, 2012, p. 14), Daarom is op zijn minst sprake van een spanningsvolle relatie tussen burgercoöperaties, overheden en marktpartijen (Gijselinckx en Van Opstal, 2008; De Moor, 2013).

Dit alles roept de vraag op waar de hernieuwde belangstelling voor coöperaties vandaan komt, wat de aard en betekenis is van burgercoöperaties als nieuwe organisatie- en bestuursvorm en hoe deze coöperaties zich tot de overheid en andere organisaties verhouden.

In dit themanummer verkennen we het antwoord op deze vragen door middel van een systematische vergelijking van burgercoöperaties op het terrein van energie, zorg, breedband, en wonen. Op deze terreinen heeft het verschijnsel burgercoöperaties een hoge vlucht genomen en konden wij bovendien onderzoekers vinden die een overzicht konden geven van de ontwikkelingen rond deze coöperaties. Om tot een vergelijking te komen hebben we de auteurs van elke bijdrage verzocht antwoord te geven op de volgende vragen:

1. Wat is de state of the art rond burgercoöperaties in de desbetreffende sector? Wat weten we over hun omvang, vorm, bestaansgronden en betekenis?

2. Wat leert de praktijk over de effectiviteit van burgercoöperaties en de wijze waarop zij al of niet erin slagen zich tot een duurzame organisatievorm voor zelforganisatie te ontwikkelen?

3. Hoe verhouden burgercoöperaties, overheden en andere organisaties zich tot elkaar en wat zijn de gevolgen hiervan?

Op het gebied van energie, zorg en breedband is de coöperatieve vorm sterk in opkomst en al op grotere schaal onderzocht. In dit themanummer nemen Hans Elzenga en Anne Marieke Schwencke (energie), Meike Bokhorst (zorg) en Koen Salemink en Dirk Strijker (breedband) ons mee in hun bevindingen. Op het gebied van wonen starten de eerste pilots, gevolgd en begeleid vanuit de kennisinstelling Platform31. Jurian Edelenbos en Meike Bokhorst gingen hierover met Tineke Lupi in gesprek om de eerste ervaringen op te tekenen. We sluiten het themanummer af met in twee 
columns een reflectie op de vier bijdragen. Tine de Moor staat stil bij de vraag wat op de onderzochte gebieden de snelle opkomst van burgercoöperaties verklaart en Justus Uitermark betoogt welke rol de overheid zou passen.

\section{Van burgerinitiatief tot burgercoöperatie}

Een proces van zelforganisatie van burgers kent in grote lijnen de volgende stadia van ontwikkeling: (1) de eerste volgers, (2) aandacht en erkenning, (3) steun van bedrijven of instituties, (4) professionaliseren, (5) schaalvergroting, en (6) afscheid van de initiatiefnemer (VNG Denktank, 2013, p. 51). Veel initiatieven van zelforganisatie beginnen als een project van enkele initiatiefnemers en eerste volgers. In dit prille stadium zoeken initiatiefnemers naar erkenning en aandacht, waarbij ze steun zoeken om het initiatief levensvatbaar te maken (VNG Denktank, 2013, p. 51; vergelijk Schulz, Van der Steen en Van Twist, 2013, p. 26). Kenmerkend voor dit stadium is de intrinsieke motivatie van de deelnemers (Huygen, Van Marissing en Boutellier, 2012, p. 13). Betrokkenen handelen vanuit een doelgericht motief (de wens om bepaalde maatschappelijke problemen op te lossen en verbeteringen door te voeren), een sociaal motief (meedoen omdat het samen actief zijn leuk en interessant is), een plichtsgebonden motief (je hoort als burger een bijdrage te leveren) of persoonlijk belang (Denters, Tonkens, Verhoeven en Bakker, 2013, p. 21-22).

Als een burgerinitiatief groeit en tot wasdom komt, ontstaat vaak een discussie over de noodzaak van professionalisering (VNG Denktank, 2013, p. 51). Zo stellen de initiatiefnemers van het burgerinitiatief Broekpolder (dat gaat over de multifunctionele ontwikkeling en beheer van een groengebied ten noordwesten van Vlaardingen) de vraag hoe zij de groei tot meer dan 100 vrijwilligers nog kunnen managen (Edelenbos, Van Meerkerk en Batenburg, 2009). ${ }^{\text {i' }}$ Voor velen is de charme van het initiatief dat burgers vrijwillig aan het gebied werken en dat er niet veel bureaucratisch regels en procedures gelden. Anderen vragen zich af of ze toch niet meer gebruik moeten maken van deskundigen en toe moeten werken naar een meer formele organisatie.

Ook door de aard van de activiteiten kan de behoefte rijzen aan een hechtere organisatie. Bijvoorbeeld omdat investeringen nodig zijn en activa beheerd moeten worden. Initiatiefnemers staan dan voor de keus van een organisatievorm, rechtsvorm en verdienmodel. Kiezen ze voor de coöperatieve vorm, dan is gemeenschappelijk investeren het verdienmodel. Maar in tegenstelling tot een 'gewoon bedrijf' is het maken van winst voor de coöperatie geen doel op zich. Van belang is dat de bedrijfsvoering rendabel genoeg is om het eigenlijke doel te kunnen realiseren. Kenmerkend is verder dat de leden eigenaar zijn van de coöperatie, zeggenschap hebben over de koers ervan en delen in de eventuele winst (Hoog, Van der Steen, Van Twist en Van Oorschot, 2014, p.12, 13).

Samenwerkende, ondernemende burgers die gedeelde zeggenschap uitoefenen over hun organisatie, hebben culturele kenmerken van een coöperatie. Een deel daarvan kiest er op enig moment voor om de organisatie ook juridisch te formaliseren tot coöperatieve vereniging. Anders dan een stichting heeft een coöperatieve vereniging leden. En anders dan een stichting en een gewone vereniging heeft een coöperatieve vereniging tot doel om in stoffelijke behoeften van leden te voorzien en kan er eventueel winst worden uitgekeerd aan leden. Tabel 1 laat zien wat de coöperatieve vereniging impliceert, vergeleken met andere rechtsvormen. 


\begin{tabular}{|c|c|c|}
\hline & Waarin komt de coöperatie overeen? & Woarin verschilt de coöperatie? \\
\hline Bedrijf & $\begin{array}{l}\text { - Het gaat om een onderneming: de } \\
\text { organisatie levert een product of dienst } \\
\text { - Rendabele bedrijfsvoering }\end{array}$ & $\begin{array}{l}\text { - Controle is niet in handen van de aandeelhouders } \\
\text { maar van de leden } \\
\text { - Eén man, één stem (stem staat niet gelijk } \\
\text { aan economische investering) }\end{array}$ \\
\hline Vereniging & $\begin{array}{l}\text { - Vrijwillig lidmaatschap } \\
\text { - Leden bepalen koers } \\
\text { - Kan ideěel doel aan ten grondslag liggen }\end{array}$ & $\begin{array}{l}\text { - Verdeling van winst over leden } \\
\text { - Vaak hogere barrières in- en uittreding }\end{array}$ \\
\hline Stichting & $\begin{array}{l}\text { - Kan ideẻel doel aan ten grondslag liggen } \\
\text { (bij de stichting is dat verplicht, bij de } \\
\text { coőperatie niet) }\end{array}$ & $\begin{array}{l}\text { - Stichting heeft geen leden om verantwoording aan } \\
\text { af te leggen } \\
\text { - Winst van stichting mag alleen gebruikt worden voor } \\
\text { ideěel doel }\end{array}$ \\
\hline
\end{tabular}

Tabel 1: Verschillen tussen coöperatie, bedrijf, vereniging en stichting (De Hoog, 2014, p. 12) ) $^{\mathrm{iii}}$

Niet elke coöperatieve vereniging is ook een coöperatie in culturele zin. Er bestaan ook juridische coöperaties die niet of nauwelijks aan de culturele kenmerken zoals zeggenschap bij de leden voldoen. Zo gebruiken bijvoorbeeld bedrijven als McDonalds, Ikea, accountancybedrijven de juridische coöperatievorm vanuit fiscale of financiële overwegingen. Het is dus belangrijk een onderscheid te maken tussen wat juridisch gezien een coöperatie is en wat cultureel gezien een coöperatie is. Tussen beide zit veel overlap, maar er bestaan ook culturele coöperaties die dat juridisch gezien niet zijn en andersom; zie figuur 1.

Figuur 1: Culturele versus juridische coöperatie (De Hoog e.a., 2014, p. 7).

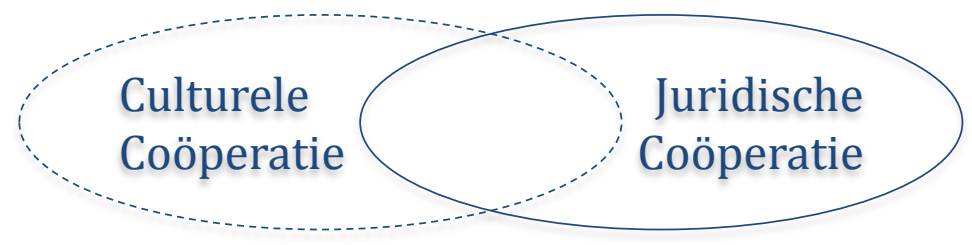

In dit themanummer benaderen we coöperaties vanuit een breed perspectief. Dat betekent dat we geïnteresseerd zijn in sectoren waarin culturele coöperaties opkomen waarvan een deel ook daadwerkelijk juridisch gekozen heeft (of zal kiezen) voor een coöperatieve vereniging als rechtsvorm. We zijn benieuwd waarom de oprichters een bepaalde organisatie- of rechtsvorm kiezen en hoe deze keuze zich verhoudt tot de aspiraties die aan een culturele coöperatie ten grondslag liggen, zoals zeggenschap van leden.

Initiatieven van zelforganisatie zetten de stap naar institutionalisering en professionalisering uit het oogpunt van effectiviteit en continuïteit, maar het is allerminst zeker of dit lukt. Coöperaties kunnen ten onder gaan aan interne moeilijkheden (bijvoorbeeld gebrekkige interne organisatie, verlies van hun eigenheid) of bezwijken onder druk van de concurrentie op de markt of gebrekkige afstemming met overheden (Defourny, Simon \& Adam, 2002; Gijselinckx, Develtere \& Raymaekers, 2007). Dat maakt ons nieuwsgierig naar het functioneren en de effectiviteit van burgercoöperaties: slagen zij er ook op de langere termijn in om te (blijven) handelen vanuit de aspiraties die aan de basis van een coöperatie liggen? Blijven zij in de belangen van hun leden voorzien? En blijven deze leden zeggenschap houden over de inhoudelijke doelen van hun initiatief en de manier waarop zij zich rond het initiatief willen organiseren? 


\section{Burgercoöperaties en de overheid}

Initiatieven van zelforganisatie zetten veel overheden aan het denken welke rollen zij zich kunnen of moeten aanmeten in relatie tot die initiatieven en de betrokken burgers. Waar de overheid bij participatieprocessen zelf kan bepalen wat de bijdrage van burgers is en onder welke voorwaarden zij deze mogen leveren, is haar rol bij initiatieven van zelforganisatie minder duidelijk. De Raad voor het Openbaar Bestuur (2012, p. 65) spreekt in haar rapport Loslaten in vertrouwen. Naar een nieuwe verhouding tussen overheid, markt én samenleving daarom van overheidsparticipatie. In deze nieuwe verhouding onderscheidt hij vijf rollen die overheden kunnen innemen ten opzichte van een initiatief, zoals in figuur 2 weergegeven.

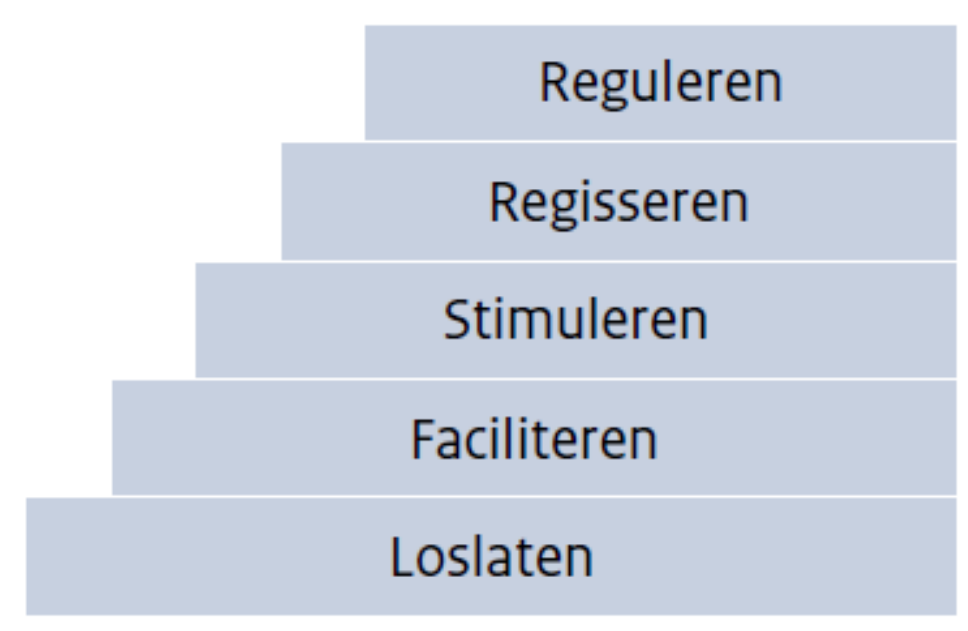

Figuur 2 Overheidsparticipatietrap (ROB 2012, p. 67)

Hierbij geldt dat er niet één ideale of beste rol bestaat. Per situatie en per onderwerp zullen overheden moeten beslissen en expliciteren welke rol zij voor zichzelf weggelegd zien. De Raad voor Openbaar Bestuur stelt $(2012$, p. 68) dat de vitaliteit van de samenleving echter wel meer ruimte krijgt op het moment dat de overheid de overheidsparticipatietrap zo min mogelijk beklimt.

De RMO heeft tegen de overheidsparticipatietrap ingebracht dat het niet om een beetje meer of minder overheid gaat, maar om een fundamentele bezinning welke taak bij wie thuis hoort. Onbetwist is dat het gaat om zeggenschap en verantwoordelijkheid; van belang is dat burgers publieke voorzieningen als hun eigendom gaan zien en daar dan ook naar eigen inzicht en met eigen verantwoordelijkheid invulling aan kunnen geven (Binnema, 2014, p. 52). Overheidsbemoeienis kan dat in de weg staan.

Voor zowel de overheid als voor degenen die actief zijn in burgercoöperaties is de omgang met elkaar een uitdaging. Want de opstelling van de overheid kan zowel belemmerend als ondersteunend zijn voor de ontwikkeling en continuïteit van coöperaties. En hoewel burgercoöperaties soms de volle steun van de overheid verdienen, is in andere situaties een afstandelijker of kritische houding meer op zijn plaats.

\section{Een vooruitblik: inzichten en patronen uit de bijdragen}


Welke antwoorden geven de bijdragen in dit themanummer op de drie vragen die in dit themanummer centraal staan? In deze paragraaf geven wij een kort overzicht van de inzichten die uit deze bijdragen naar voren komen, van de uitdagingen die daaruit voor burgercoöperaties, overheden en andere organisaties voortkomen en van de vragen die onbeantwoord blijven en (nader) onderzoek behoeven. Bovenal poogt deze paragraaf een vooruitblik te geven en lezers uit te nodigen van de verschillende bijdragen kennis te nemen.

Wat is de 'state of the art' met betrekking tot burgercoöperaties?

Recent betoogde Rotmans (2015) dat de opkomst van burgerinitiatieven en coöperaties het begin laten zien van een transitie naar een nieuwe manier van organiseren en besturen. De artikelen in dit themanummer laten zien dat de bijdragen van burgercoöperaties op de besproken beleidsterreinen aan de levering van publieke producten en diensten nog maar beperkt is en dat het allerminst zeker is dat deze initiatieven succesvol en duurzaam zijn. Zo zou het aantrekken van de woningmarkt grote gevolgen kunnen hebben voor de voedingsbodem die tot voor kort bestond voor wooncoöperaties. Het lijkt ons daarom te vroeg om uitspraken te doen over het succes van burgercoöperaties of om deze te zien als nieuw besturingsmodel dat een transitie in het bestuurlijk landschap teweeg zal brengen. Burgercoöperaties moeten zich nog bewijzen. In de tussentijd is dit verschijnsel opvallend genoeg om na te gaan hoe deze initiatieven functioneren, de welke stimulansen en belemmeringen zij op hun weg vinden en onder welke condities zij zich kunnen ontwikkelingen en een duurzaam succes kunnen worden. Dit zijn zaken waar de bijdragen in dit themanummer inzicht in geven.

Waardoor zijn burgercoöperaties zo sterk in opkomst? Vanwaar de hernieuwde aandacht voor coöperaties? Bezuinigingen en een terugtredende overheid houden in dat de burger minder van de overheid kan verwachten. Maar ook privatisering, verzelfstandiging, marktwerking en liberalisering spelen een belangrijke rol, zo blijkt uit de bijdragen. De markt blijkt de burger minder te bieden dan er van werd verwacht.

In alle vier de sectoren voorziet het aanbod niet in de vraag van burgers. Zo is het aanbod in de telecom- en zorgsector ontoereikend in dun bevolkte gebieden, omdat het voor aanbieders geen rendabele investering is. Plattelandsgebieden blijven zo verstoken van eigentijds internet en zien voorzieningen op het gebied van zorg en welzijn verdwijnen. In grootschalige zorginstellingen staat de menselijke maat onder druk. Traditionele leveranciers in de energiesector investeren onvoldoende in duurzame energie, en in de woonsector zijn er te weinig betaalbare koopwoningen voor mensen met lage en middeninkomens.

De overheid biedt onvoldoende tegenwicht aan het falen van de markt. Europese regelgeving verbiedt staatsteun en de overheid stelt zich afwachtend op of komt met weinig slagvaardig beleid om tekortkomingen in de markt te repareren. Daarmee vormt zich een vruchtbare bodem voor coöperaties, die typisch ontstaan wanneer noden of behoeften niet door de staat of markt worden ingelost. Technologische vernieuwingen maken het bovendien eenvoudiger voor burgers om zelf met alternatieve diensten of producten te komen of om daarvoor het sociaal en financieel kapitaal bij elkaar te krijgen.

Het culturele karakter van burgercoöperaties komt tot uiting in de motieven van de deelnemers. Deze zijn vaak niet uitsluitend gericht op het realiseren van persoonlijk belangen (de wens om over eigentijds internet te beschikken, een betaalbare woning te verwerven of in de toekomst zelf een 
beroep te kunnen doen op informele zorg), maar ook op het leveren van een bijdrage aan de gemeenschap. Burgers richten coöperaties ook op vanuit onvrede over de dienstverlening van reguliere commerciële of semipublieke organisaties, vanuit gedeeld eigenbelang om collectieve voorzieningen te realiseren en vanuit behoefte aan zeggenschap en regie over de eigen leefomgeving. De betrokken burgers willen dan met het realiseren van breedband bijdragen aan het overeind houden van voorzieningen op het platteland, investeren in duurzame energie, met kleinschalige zorg inspelen op de veranderde zorgvraag en vernieuwende woonvormen ontwikkelen. Schaalvergroting en bedrijfsmatig werken kunnen tot een gevoel van vervreemding leiden en de culturele coöperatie is een reactie hierop.

\section{Effectiviteit, duurzaamheid en zeggenschap}

Wat leren de bijdragen over de effectiviteit en de duurzaamheid van zelforganisaties en burgercoöperaties? Maken ze de verwachtingen waar?

Enerzijds gaat het om de zorg voor de belangen van de deelnemers aan de coöperatie: worden betaalbare, toegankelijke, kleinschalige, duurzame en kwalitatief goede producten en diensten geleverd (energie, zorg, woningen, aansluiting op het internet) en is die levering gegarandeerd? De bijdragen laten zien dat het te vroeg is om deze vraag te beantwoorden. Er zijn afvallers en er zijn bewezen duurzame successen, vooral bij de energiecoöperaties. De aanwezigheid van een verdienmodel of business case wordt als belangrijke succesfactor gezien. Niet in alle gevallen is die aanwezig. In de woningsector is het denkbaar dat wooncoöperaties met het aantrekken van de woningmarkt minder aantrekkelijk worden in vergelijking met woningen die door de markt worden aangeboden. En in de energiesector zijn verdienmodellen voor de productie van energie moeilijk te realiseren. Voor het merendeel van de huidige golf van coöperaties geldt dat ze pril zijn, dat ze nog niet in het stadium verkeren dat ze de beloofde producten en diensten leveren, of dat ze nog niet systematisch geëvalueerd zijn.

Anderzijds gaat het om de culturele dimensie van de coöperaties: worden doelstellingen op het vlak van autonomie en zeggenschap door middel van mede-eigenaarschap van de leden gerealiseerd? Uit de bijdragen blijkt dat deze doelstellingen op gespannen voet kunnen staan met het streven naar de effectieve en duurzame levering van producten en diensten. Hoewel sommige coöperaties op vindingrijke wijze erin slagen de kennis, kunde en vaardigheden van hun leden te mobiliseren, laten de bijdragen ook zien dat met deze inzet niet kan worden volstaan als het initiatief in omvang groeit. Er zijn dan investeringen, een meer bedrijfsmatige manier van werken en kennis en ondersteuning van professionals nodig. Samenwerking met andere organisaties (overheid, professionele dienstverleners en marktpartijen) biedt dan uitkomst, maar creëert tegelijkertijd afhankelijkheid. De vraag hoe coöperaties de relaties met deze partijen vorm kunnen geven en onder welke condities zij erin kunnen slagen tegelijkertijd hun autonomie veilig te stellen, wordt in de bijdragen als cruciale uitdaging gesignaleerd.

Een andere achilleshiel van de burgercoöperatie is de mate waarin de coöperatie erin slaagt om een kritische massa aan deelnemers te mobiliseren. Hier speelt het spanningsveld tussen individuele belangen en de culturele dimensie van de coöperatie. Zijn individuele burgers bereid te investeren en risico's te nemen, en daarbij ook solidair met anderen te zijn. Het kan dan gaan om de vraag of leden van een dorpscoöperatie bereid zijn patiënt te worden van de beoogde dorpshuisarts, maar ook om de vraag of leden van een breedbandcoöperatie bereid zijn een hogere prijs te accepteren om een 
buurman die verder van het hoofdnet woont ook een aansluiting te gunnen. Hier speelt de aanwezigheid van een goed verdienmodel een rol, maar ook de overredingskracht van betrokkenen in de coöperatie en de cohesie binnen de coöperatie.

Initiatiefnemers kiezen de coöperatie als organisatievorm om via eigenaarschap zelfbeheer en zeggenschap te borgen, maar tegelijkertijd roepen zij vaak parallelle hulpconstructies in de vorm van bijvoorbeeld stichtingen (zorg, energie) of besloten vennootschappen (energie) in het leven om die zeggenschap aan banden te leggen. Ook hier blijkt weer het spanningsveld tussen effectiviteit en zeggenschap: zetten de coöperaties met deze hulpconstructies hun leden buiten spel en verloochenen ze daarmee hun identiteit, of zijn dit juist voorbeelden van slimme en innovatieve manieren om met het dilemma tussen de behoefte aan professionele bedrijfsvoering en zeggenschap van leden om te gaan? De bijdrage over zorgcoöperaties stelt dat te hoge ambities en een te grote schaal (ingegeven door het realiseren van een goede business case, of opgezweept door het enthousiasme van overheden) het succes van de coöperatie kunnen ondermijnen, omdat te veel gevraagd wordt van de betrokken leden en het bestuur. Ook kunnen deze ambities tot verdergaande professionalisering en bureaucratisering aanzetten, die spanningen kunnen veroorzaken met de vrijwilligersmentaliteit binnen coöperaties. Onderzoek naar hoe leden het functioneren van hun coöperatie waarderen, kan meer zicht geven op de mate waarin coöperaties erin slagen met dit dilemma om te gaan.

\section{Burgercoöperaties en overheden}

Hoewel sommige overheden enthousiast zijn over de opkomst en potenties van burgercoöperaties, laten de bijdragen zien dat althans een deel van de gemeenten afwachtend of zelfs argwanend tegenover deze initiatieven staan. Het lijkt erop dat zij pas na bewezen succes en navolging bereid zijn burgercoöperaties te faciliteren en te stimuleren. Dat gebeurt dan door bepaalde kosten te betalen of vergaderruimten en communicatiekanalen van de gemeente beschikbaar te stellen. Zeker in financieel opzicht zijn lokale overheden terughoudend, omdat burgerinitiatieven in hun ogen niet afhankelijk van de overheid zouden moeten zijn. Maar ook omdat ze vaak aanzienlijk hebben moeten schrappen in subsidies om de eigen begroting op orde te krijgen. Daar tegenover staat dat overheden zeker belang kunnen hebben bij coöperaties bijvoorbeeld omdat deze deels taken kunnen overnemen, die overheden vanwege bezuinigingen niet langer kunnen uitvoeren. De zorgcoöperaties zijn hiervan een pregnant voorbeeld.

De Rijksoverheid kan belemmeringen in wet- en regelgeving wegnemen of gemeenten en andere organisaties stimuleren om ruimte te geven aan of zaken te doen met burgercoöperaties. Zo verplicht de Rijksoverheid de woningcorporaties in de nieuwe woningwet om bewoners die een wooncoöperatie willen oprichten een startsubsidie van 5.000 euro te geven. In de nieuwe Wet Maatschappelijke Ondersteuning is vanaf 1 januari 2015 een 'right to challenge' opgenomen waardoor georganiseerde burgers al dan niet samen met professionele aanbieders een alternatief bod mogen doen als ze denken dat ze (een deel van) de zorgtaken beter kunnen uitvoeren. Bij energiecoöperaties is de steun van de rijksoverheid noodzakelijk om coöperaties (zon en wind) levensvatbaar te krijgen. Zo is er in het Energieakkoord met de LDE+ subsidieregeling (voor windenergie), het participatieplan (binnen de Omgevingswet) en het de postcoderoosregeling. Ook krijgen zonne-energiecoöperaties een salderingsregeling aangeboden zodat ze volledig vrijgesteld 
zijn van energiebelasting. Het cliché dat windmolens niet op wind maar op subsidie draaien, is dus tot op zekere hoogte juist.

De vraag is tot hoever de stimulerende en faciliterende houding van de overheid kan en moet gaan. Ontstaat er niet een te grote afhankelijkheidsrelatie tussen coöperatie en overheid, zeker als je bedenkt dat de opkomst van zelforganisaties juist een reactie was op overheidsoptreden en een te grote overheidsbemoeienis de lichtvoetigheid, flexibiliteit en vrijwilligersmentaliteit van coöperaties kan aantasten? Daarnaast kan een overheid in een spagaat terecht komen als het steun aan een specifieke groep belanghebbenden geeft, terwijl dit vanuit maatschappelijk belang te verdedigen is. Als bijvoorbeeld een energiecoöperatie windmolens wil bouwen en stuit op verzet van omwonenden, kan een gemeente in een lastig parket komen te zitten.

De terughoudendheid van overheden is dus niet alleen ingegeven door onterechte koudwatervrees, organisatorische complicaties of weerstand tegen het uit handen geven van controle en macht. $\mathrm{Er}$ zijn overwegingen die deze voorzichtigheid kunnen rechtvaardigen. Allereerst kan overheidsbemoeienis leiden tot ondersteuning van burgercoöperaties die weinig kans op overleven hebben. Daarnaast kunnen burgercoöperaties met hun aanbod publieke voorzieningen vervangen of ermee concurreren. Doordat burgercoöperaties grotendeels zelf kunnen bepalen wie mag deelnemen, bestaat het risico datzij hun aanbod voor een selectieve groep openstellen, met 'cherry picking' en 'cream skimming' tot gevolg. Hierdoor kunnen publieke voorzieningen onder druk komen door afnemend gebruik (vergelijk Schulz e.a., 2013, p. 56). Ook kan dit tot segregatie en uitsluiting leiden (vergelijk Uitermark, 2014). Burgercoöperaties kunnen ook op oneigenlijke wijze concurreren met marktpartijen, zeker als zij financiële ondersteuning krijgen, of als voor hen lichtere regelgeving geldt. Voorts kan er concurrentie in democratisch opzicht ontstaan als de overheid als democratisch gekozen gezag zeggenschap wil houden, terwijl burgers aan de andere kant de democratische instituties en spelregels van het representatieve model 'omzeilen' door zelf een maatschappelijke kwestie aan te pakken (Van Stipdonk, 2014, p.18). Een voorbeeld zijn de zorgcoöperaties die eigen werkwijzen ontwikkelen, terwijl de overheid kwaliteitseisen probeert te handhaven ter bescherming van zwakkeren. Voorts kan het interne functioneren van een burgercoöperatie de overheid zorgen baren, maar ook het type activiteiten dat wordt ontwikkeld, bijvoorbeeld omdat deze maatschappelijk ongewenst worden geacht of zelfs illegaal.

Dit alles betekent overigens niet dat de overheid altijd een prominente rol speelt bij de opkomst van burgercoöperaties. De overheid komt eigenlijk pas in beeld als burgers om enige vorm van ondersteuning vragen, tenzij de overheid een overtreding constateert, een stimulerende rol heeft gespeeld en ook betrokken was bij de vorming van (spel)regels voor de coöperatie. Vanuit burgercoöperaties bezien kan steun in de vorm van middelen, kennis en praktische ondersteuning van overheden cruciaal zijn om de continuïteit en effectiviteit van het burgerinitiatief te borgen. Maar het accepteren van de steun van de overheid of andere partijen, is niet zonder risico's. Het accepteren van steun kan ten koste gaan van de zelfstandigheid en de vitaliteit van het initiatief. Daarbij is overheidssteun vaak geen vrijblijvende zaak. De overheid heeft een eigen agenda, zal voorwaarden en regels willen stellen en zo kunnen burgercoöperaties geleidelijk aan verworden tot 'helden van de terugtocht' (Frissen, 2014), die taken uitvoeren die de overheid niet zelf meer voor haar rekening wil nemen.

\section{De coöperatie: spelbepaler of speelbal in een nieuw samenspel?}


Afgelopen decennium is de coöperatie als organisatievorm herontdekt. Het fenomeen bestaat natuurlijk al veel langer (De Moor, 2013). Dit themanummer inventariseert en vergelijkt the state of the art van burgercoöperaties op het terrein van energie, zorg, breedband en wonen. Het biedt inzicht in de ontwikkelingscyclus van burgercoöperaties en de manier waarop zij zich nestelen in de sector. Leidende vraag daarbij is hoe effectief en duurzaam burgercoöperaties zijn en hoe zij zich verhouden tot overheden en andere organisaties. Hoewel het jonge organisaties zijn die zichzelf deels nog moeten bewijzen, zijn de koplopers een bron van inspiratie, innovatie en navolging. Vaak worden coöperaties opgericht uit een vorm van ontevredenheid over falend of uitblijvend overheidsbeleid. In deze eerste fase van de groei zetten coöperaties zich vaak af tegen alles wat markt of publiek is. Maar voor de opstart en het voortbestaan hebben coöperaties zeker in de zorg, energie en wonen ook hulp van andere actoren nodig: een subsidie van de overheid (bijdrage over energie), kennis en deskundigheid van andere instellingen (bijdrage zorg, maar ook breedband) en draagvlak en steun vanuit de maatschappij (bijdrage wonen). Veel coöperaties kunnen het niet alleen. Dit inzicht ontstaat ook langzamerhand bij coöperaties en lijkt te horen bij het groei- en ontwikkelproces van coöperaties.

Burgercoöperaties moeten hun plek zien te vinden in het bestaande institutionele landschap van private, publieke en maatschappelijke organisaties. Hierdoor kan een interessante nieuwe vorm van publiek-privaat-maatschappelijk samenwerking ontstaan, waarbij de coöperaties relaties met andere partijen ontwikkelen, managen en onderhouden en zo tot een duurzaam en effectief partnerschap komen. Bij de leercurve die zij doormaken hoort daarom ook het verwerven van competenties gericht op het opbouwen en in stand houden van een eigen netwerk. Dit relatiespel is van een andere orde dan het aansturen van vrijwilligers binnen de eigen coöperatie en vergt competenties die in het publieke en private domein vaak al meer ontwikkeld zijn. Coöperaties moeten het samenwerkingsspel leren mee te spelen. Het gevaar bestaat anders dat andere partijen de spelbepalers worden, en burgercoöperaties worden ingezet voor de doelstellingen van anderen (zoals het behalen energieafspraken, en decentralisatie/bezuinigen doeleinden in zorg). Voor alles staan coöperaties dan ook voor de opgave het spel mee te leren spelen, teneinde geen speelbal van gevestigde partijen worden.

\section{Literatuur}

Binnema, H. (2014). Terugtrekken of opzij stappen? Beleidsadviezen over minder overheid en meer samenleving. Bestuurskunde 23 (3), 47-55.

Boer, N. de \& Lans, J. van der (2011). Burgerkracht. De toekomst van het sociaal werk in Nederland. Den Haag: Raad voor Maatschappelijke Ontwikkeling.

Brouwer, J. \& Engbersen R. i.s.m. Van der Schaar, M. \& Schreuders, H. (2013) Zelforganisatie gaat niet vanzelf. Evaluatie experimenten met bewonersinitiatieven New Towns, Den Haag, Plaform31. 
Defourny, J., Simon M. \& Adam S. (2002), De coöperaties in België: een beweging met toekomst. Brussel: Editions La Pire.

Denters, B., Tonkens, E., Verhoeven I. \& Bakker, J. (2012) Burgers maken hun buurt, Den Haag, Platform31.

Edelenbos, J., I. van Meerkerk en Y. Batenburg (2009), Burgerinitiatief Vlaardingen en de Veerkracht van Instituties, in: Bestuurskunde, nr.1.pp.81-91.

Frissen, P (2014) Taptoe: de echte helden van de terugtocht. Bestuurskunde, nr. 3 (23), pp 66-58

Gijselinckx C. \& Van Opstal W. (2008). Coöperatief ondernemen In W. van Opstal, C. Gijselinckx \& P. Develtere (red.), Coöperatief ondernemen in België: theorie en praktijk (pp. 17-38). Leuven: ACCO.

Gijselinckx, C, Develtere, P. \& Raymaekers, P. (2007) Coöperative vernieuwing en duurzame ontwikkeling, Leuven: HIVA-K.U.Leuven/ARCO.

Habermas, J. (1981) Theorie des Kommunikativen Handeln, Frankfurt: Suhrkamp.

Heijden, J. van der, Mark, L. van der, Meiresonne, A. \& Zuylen, J. van (2007). Help! een burgerinitiatief. Den Haag: InAxis, Ministerie van Binnenlandse Zaken en Koninkrijksrelaties.

Hendriks, F. \& Wijdeven, T.M.F. van de (red.) (2014) Loshouden en meemaken: Over samenredzaamheid en overheidsparticipatie. Den Haag: Platform 31

Heylighen, F. (2001). The science of self-organization and adaptivity. In: L.D. Kiel (Ed.). Knowledge management, organizational intelligence and learning, and complexity. The Encyclopedia of Life Support Systems.

Hoog, J. de, Steen, M. van der, Twist M. van \& Oorschot, K van (2014) De herontdekking van de coöperatie. Voorbij publiek en privaat. Working paper van de NSOB Denktank, Den Haag: NSOB

Houwelingen P. van, Boele A. en Dekker, P. (2014) Burgermacht op eigen kracht? Een brede verkenning van ontwikkelingen in burgerparticipatie, Den Haag, Sociaal Cultureel Planbureau

Huygen, A., Marissing, E. van \& Boutellier, H. (2012) Condities voor zelforganisatie, Verwey-Jonker Instituut

Jantsch, E. (1980). The self-organizing universe: Scientific and human implications of the emerging paradigm of evolution. Pergamon Press, Oxford.

Ministerie van Binnenlandse Zaken en Koninkrijksrelaties (2013) De Doe-democratie. Kabinetsnota ter stimulering van een vitale samenleving, Den Haag

Moor, T. de (2013). Homo Cooperans. Instituties voor collectieve actie en solidaire samenleving, oratie, Utrecht: Universiteit van Utrecht.

Nienhuis, I. (2014) Zelforganisatie komt van onderop en is niet af te dwingen, Sociale Vraagstukken, 6 december 2014 
Oude Vrielink, M. J. \& Wijdeven, T. M. F. van de (2008). Bewonersinitiatieven: een prachtkans voor wijken? Bestuurswetenschappen, 62(3), pp. 66-83.

Oude Vrielink, M. J. \& Verhoeven, I. (2011), Burgerinitiatieven en de bescheiden overheid. Beleid en Maatschappij, 38(4), pp. 377-387.

Raad voor het Openbaar Bestuur (2012) Loslaten in vertrouwen. Beschouwingen van adviesraden over een nieuwe verhouding tussen overheid, markt én samenleving, Den Haag

Schulz, M., Steen, M. van der \& Twist, M. van (2013) De koopman als dominee, Boom/Lemma.Stipdonk, V.P. van (2014) 'Wat te doen met de doe-democratie?', in: Jaarboek Vereniging van Griffiers, pp. 13-21.

Tonkens E. H. (red.), Tussen onderschatten en overvragen. Actief burgerschap en activerende organisaties in de wijk. Amsterdam: Uitgeverij SUN, 2009.

Twist, M. van, Steen, M. van der \& Karré, P.M. (2009) Als burgers het heft in eigen handen nemen: van representatieve naar doe-het-zelf democratie, Res Publica, 4, pp. 521-535

Uitermark, J. (2014) Verlangen naar Wikitopia, Rotterdam, Erasmus Universiteit Rotterdam, 2014

Velden, J. van der (2010), Zelforganisatie in stedelijke vernieuwing, Den Haag, KEI-A5

VNG Denktank (2013) Van eerste overheid naar eerst de burger. Over maatschappelijke initiatieven die de lokale overheid uitdagen, jaarbericht 2013.

Wijdeven, T. van de \& Hendriks F. (2010) Burgerschap in de doe-democratie, Den Haag, NICIS Institute

\section{Eindnoten}

\footnotetext{
'Gebaseerd op de definities van de International Co-operative Alliance, Cooperatives UK, COOP FR, Cooperatives Europe

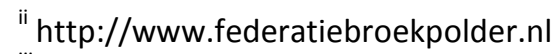

iii http://www.tijdvoorsamen.nl/art/uploads/files/4\%20cooperaties.pdf
} 